\title{
Transnationalization of Agricultural Cooperatives in Europe
}

\author{
Jos Bijman, Perttu Pyykkönen \& Petri Ollila*
}

\section{Introduction}

Agricultural cooperatives in Europe have recently started a new phase in their internationalization strategies. For many decades, cooperatives have expanded internationally through exporting and investing in foreign distribution networks, either individually or in joint ventures with foreign partners. However, over the last 15 years an increasing number of cooperatives has expanded internationally by inviting foreign farmers to become members. Cooperatives that have members in two or more countries have been called transnational cooperatives. ${ }^{1}$

Currently, the most transnational agricultural cooperative in Europe is the dairy cooperative Arla Foods. Arla was established in the year 2000 by the merger of MD Foods from Denmark and Arla from Sweden. After subsequent mergers with Hansa Milch and MilchUnion Hocheifel (both from Germany) and Milk Link (UK) and Walhorn (Belgium), Arla Foods now has members in Denmark, Sweden, Germany, Belgium and the UK but also in Luxembourg and the Netherlands as Walhorn also had members in those countries. The second most transnational cooperative, also in dairy, is FrieslandCampina, headquartered in the Netherlands and with members in three countries: Netherlands, Germany and Belgium. Is it a coincidence that these two transnational cooperatives both are in dairy and both have their headquarters in a small country (respectively Denmark and the Netherlands)?

Internationalization, and even more transnationalization, has always been a much debated issue among the cooperative members. While exporting as an internationalization strategy has always received broad support, foreign investments have often encountered substantial

* Dr. Jos Bijman, Management Studies Group, Wageningen University. Dr. Perttu Pyykkönen, Pellervo Economic Research PTT, Helsinki. Dr. Petri Ollila, Department of Economics and Management, University of Helsinki. This article is based on the results of the project 'Support for Farmers' Cooperatives (SFC)' which was contracted by the European Commission, DG Agriculture and Rural Development (Contract Number: 30-CE-0395921/00-42).

1. Federation of Danish Co-operatives 2000. In this article, a transnational cooperative is defined as a cooperative with members in more than one country, while an international cooperative is a cooperative with members in only one country and non-member farmer-suppliers or farmercustomers in one or more other countries. criticism. As cooperatives generally are conservative in their business decisions and investing abroad is usually more risky, the decision to invest in foreign activities was not taken lightly. However, inviting foreign farmers to become members raises even more discussion. As international membership leads to higher costs in member relations and in the governance of the cooperative, due to differences in history, culture and language, domestic members are reluctant to accept foreign membership. Ollila et al. found that the most loyal members were the most reluctant towards foreign membership. ${ }^{2}$ Nevertheless, several cooperatives in Europe have embarked upon the course of transnationalization. This article seeks to explore this trend and to explain why cooperatives, despite the obvious disadvantages, continue to grow transnationally.

Most of the literature on internationalization of agricultural cooperatives discusses the activities of the cooperative firm in exporting, setting up joint ventures and establishing or acquiring foreign production facilities. ${ }^{3}$ Besides the work of Nilsson and Madsen, research on transnational cooperatives is rare. ${ }^{4}$ Our article is the first to provide original data on international membership in agricultural cooperatives for the whole of the European Union.

We do not seek to answer all questions as to the why and how of transnationalization of agricultural cooperatives. Our data and research methods do not allow such a comprehensive treatment of the topic. Rather, our ambition is more modest. Our objective is to present and discuss recent data on the number and type of transnational cooperatives in the EU, as any further discussion of the topic should start with the facts. Are there differences between countries and sectors to be found and what explains these differences? What are the motives for cooperatives to become international/transnational?

The article is structured in six parts, beginning with this introduction. In section 2, we discuss the strategies of internationalization and transnationalization of agricultural cooperatives, and we present examples of cooperatives following such strategies. In sections 3 and 4, we present the results of our empirical study into the incidence of transnational membership in the EU. In section 5 , we discuss our findings, reflecting on the motives

\footnotetext{
Ollila et al. 2014

See, e.g., Guillouzo \& Ruffio 2005; Theuvsen \& Ebneth 2005; Heyder et al. 2011.
}

4. Nilsson \& Madsen 2007 
for becoming or not becoming a transnational cooperative. Section 6 draws conclusions on the future of transnational cooperatives.

\section{Strategies of Internationalization and Transnationalization}

Why do agricultural cooperatives pursue a transnationalization strategy? We answer this question in three steps. First, we discuss the general motives for companies in the agrifood industry to pursue an internationalization strategy. Second, we zoom in on the process of internationalization of cooperatives, as we assume that internationalization strategies of cooperatives are partly similar and partly different from those of non-cooperative companies. Third, we discuss transnationalization itself: why do cooperatives accept members in different countries and what are the implications for the strategy and structure of the organization?

\subsection{General Motives for Internationalization Strategies}

Globalization and increasing market integration has pushed companies in the food industry to operate internationally. Internationalization has been a means to achieve economies of scale, to be able to negotiate with large retail customers and to be able to assure product quality and safety throughout the entire food chain from input material to final product. Internationalization is also used as a pre-emptive strategic step to protect current markets; that is, companies invest in a foreign market before the competitor will do so.

Motives for companies in the European agrifood industry to expand internationally can be both internal and external. External motives result from changes in the economic and institutional environment, such as increased competition or legislative reform. There are at least three important trends in the European market for agrifood products that influence the motives for internationalization of companies.

First, the liberalization of the European and world markets for agricultural products (in sum, globalization) has led increased competition in the home markets. This liberalization of food markets of the European Union occurred through eliminating trade restrictions and through harmonizing rules and regulations for food products. Increased competition, both within the EU and from third countries, forces companies to increase their scale of operation and to lower their production costs.

Second, an increasing concentration among food retailers has led to an important change in competition dynamics, speeding up the internationalization of food companies. Firms like Ahold (NL), Aldi and Metro (Germany), Tesco (UK), Carrefour and Auchan (France) and Wal-Mart (USA) have become global players and are using their large purchasing power. In addition, most supermarket chains have established European purchasing organizations that negotiate hard with the food industry on prices and terms of delivery. In response to this increasing power play by food retailers, suppliers of food also need to become larger in order to pose sufficient countervailing power. Obtaining the necessary scale has often forced them to go beyond the boundaries of their home country.

Third, quality assurance as well as product development have become increasingly important in agrifood markets. Consumers demand variation, convenience, uniform products and guaranteed quality. ${ }^{5}$ Not only the quality of the final product matters, but increasingly also the quality of its production process: issues like animal welfare and environmental impact are increasingly important for consumers. Therefore producers make greater efforts in the field of product innovation and quality assurance. The necessary investments call for increasing size, often including a more international scale of operation.

While these trends push food companies to expand abroad, the actually pursued internationalization strategy may differ. Classical internationalization strategies include exporting, licensing and franchising, strategic alliances and joint ventures and foreign direct investment. ${ }^{6}$ Although foreign direct investments and joint ventures require substantial investments and entail high risk, ${ }^{7}$ they provide access to the local resources that the foreign partner brings in.

Next to the external motives for agrifood companies to go international, there may be internal motives related to the goal of better exploiting current resources and capabilities. Dunning has distinguished four such motives ${ }^{8}$ :

- Resource seeking: getting access to essential or additional resources, such as raw materials;

- Market seeking: opening new markets in foreign countries for existing products;

- Efficiency seeking: obtaining economies of scale and scope;

- Strategic assets seeking: getting access to specialized knowledge and skills, intangible assets (such as patents) or brands.

\subsection{The Internationalization Process of Cooperatives}

Cooperatives operate in the same economic and institutional environment as non-cooperative businesses and thus experience the same trend of increasing competition. To a certain extent, cooperative and non-cooperative businesses respond similarly to increasing competition by acquiring foreign companies to get access to local brands and local distribution networks, by acquiring local processing companies to obtain access to the local base of raw material and by speeding up the inno-

\footnotetext{
Trienekens \& Zuurbier 2008

Rugman \& Collinson 2009

Ollila 1995

Dunning 1992.
} 
vation process and spreading the costs of R\&D over a larger volume of products.

However, there are also differences in internationalization strategies of cooperatives compared to investorowned firms (IOFs). One of the special features of the cooperative is that it maintains a narrow product portfolio, also in its foreign operations. Hendrikse and Van Oijen found that Dutch cooperatives are less diversified than non-cooperative companies. ${ }^{9}$ Thus, both in resource seeking and market seeking, cooperatives are more likely to be specialized than IOFs. Cooperatives also put more emphasis on the efficiency seeking motive than on other motives and show a higher degree of risk aversion. ${ }^{10} \mathrm{~A}$ clear example of this efficiency focus is the internationalization strategy pursued by most of the European sugar cooperatives, which have mainly invested in acquiring foreign sugar factories to integrate them into larger production units, thus gaining economies of scale. ${ }^{11}$

\subsection{Strategies That National Cooperatives Use to Become Transnational}

The key difference between internationalization of cooperatives and internationalization of IOFs arises when cooperatives invite foreign farmer-suppliers to become members. The internationalizing cooperative would then become a transnational cooperative.

Publications on transnational cooperatives are scarce and most of them present only anecdotal evidence of cooperatives that have members in more than one country. Van Bekkum and Van Dijk present several examples of transnational dairy cooperatives in the Netherlands, Germany, Belgium and Luxembourg. ${ }^{12}$ Bijman and Van Tulder discuss three Dutch cooperatives that became transnationals in the 1990s. ${ }^{13}$ The Federation of Danish Co-operatives presents seven cases of agricultural cooperatives with foreign members: four Dutch cases, one German/Belgium/Luxembourg case, one Sweden/ Denmark case and one Sweden/Finland case. ${ }^{14}$

Nilsson and Madsen were the first authors to systematically explore the process of how a national cooperative becomes a transnational cooperative. ${ }^{15}$ They found four different strategies:

- Strategy 1 entails that a cooperative from country A recruits farmers from country $B$ (often a neighbouring country) to become members;

- Strategy 2 entails that a cooperative from country A acquires a processing company in country $\mathrm{B}$ and invites the suppliers of the acquired company to become members;

- Strategy 3 means that farmers from two or more countries establish a new, transnational cooperative; and

\footnotetext{
9. Hendrikse \& Van Oijen 2002.

10. Krogt et al. 2007.

11. Filippi et al. 2012.

12. Van Bekkum et al. 1997

13. Bijman \& Van Tulder 1999

14. The Federation of Danish Co-operatives 2000

15. Nilsson \& Madsen 2007
}

- Strategy 4 entails that a cooperative from country A will merge with a cooperative from country $\mathrm{B}$.

These strategies have some specific examples, characteristics and organizational consequences which we will briefly discuss in the next paragraphs.

Strategy 1 is pursued particularly by cooperatives that seek to expand their resource base. In the 1980s and 1990s, when agricultural cooperatives in Europe started to invest abroad, this was the most important reason for cooperatives to become transnational. ${ }^{16}$ For instance, in the 1980s the Dutch starch potato cooperative Avebe invited potato farmers in Germany (just on the other side of the border) to become suppliers and members. Avebe wanted to grow but due to EU legislation on starch potato such an expansion was not possible in the Netherlands. Avebe invited German suppliers to become members in order to have a guaranteed supply (as starch potato processing is a capital intensive activity with the most efficient scale of processing at a high volume), while farmers wanted to become member in order to have a guaranteed outlet for their starch potatoes (for which no alternative market exists). A more recent case of international resource seeking can be found among the auction cooperatives in the ornamentals industry (mainly in the Netherlands) and in the fruit and vegetables industry (e.g. in Belgium and the Netherlands). These cooperatives have invited foreign suppliers to become members in order to assure sufficient supply and a broad variety of products at the auction, thereby remaining an attractive market place for wholesale and retail customers.

Strategy 1 was also pursued by supply cooperatives expanding their market base internationally. In the 1990s, Dutch feed cooperative ACM had members in Germany. Similarly, the Swedish supply cooperative Norrbottens Lantmän had members in Finland. As transport cost are a substantial factor in the price of feed, for feed cooperatives located close to a border it is more efficient to seek a market on the other side of the border than further away in the home country.

Strategy 2 starts with the acquisition of a foreign processing facility and has been followed by German dairy cooperative Milch-Union Hocheifel (MUH). In the 1980s, MUH acquired several dairies in Belgium and Luxembourg and offered the local suppliers membership of the cooperative to guarantee the supply of milk to the acquired dairies. Another example is the 1997 joint venture between Dutch dairy cooperative Campina and German cooperative Mölkerei Köln-Wuppertal $(\mathrm{MKW})$. This joint venture implied that Campina took over the processing activities of MKW (which had serious financial problems). Not long after the start of the joint venture, the members of $\mathrm{MKW}$ were invited to become members of Campina, and MKW was dissolved. Two years later, in 1999, the German dairy IOF Emzetts was acquired, and in 2004 Strothmann was

16. Bijman \& Van Tulder 1999; Federation of Danish Co-operatives 2000. 
bought. Suppliers of Emzetts and Strothmann were also invited to become members of Campina.

Strategy 3 entails that farmers from several countries establish a new transnational cooperative. This is a rather recent phenomenon. Nilsson and Madsen assumed that there were no cases of establishing a completely new cooperative by farmers from two or more countries. ${ }^{17}$ However, we found several examples of this strategy in the vegetables industry of Belgium and the Netherlands (see below).

Strategy 4 has as a classical example the merger between Danish dairy cooperative MD Foods and Swedish dairy cooperative Arla into Arla Foods in 2000, and the subsequent mergers with German and UK cooperatives.

A fifth strategy of establishing a transnational cooperative, not mentioned in the study by Nilsson and Madsen, is the setting up of a European Cooperative Society (SCE, according to its Latin abbreviation). ${ }^{18}$ With the adoption by the European Commission of the Regulation on the Statute for the European Cooperative Society, farmers from different EU Member States have a legal tool to establish a SCE. ${ }^{19}$ The difference with strategy 3 above is that the new transnational cooperative is not regulated under national cooperative law but under European cooperative law (however, the EU Regulation still has to be implemented in a national SCE statute, and the cooperative still has to choose its seat in one Member State). The SCE is not popular, as few exist and none of them in agriculture. ${ }^{20}$

\section{Recently Collected Data Provides New and More Detailed Insights}

The Support for Farmers' Cooperatives (SFC) project has collected data on international and transnational cooperatives in 2011. ${ }^{21}$ Cooperative experts in all $27 \mathrm{EU}$ Member States have collected information on cooperatives in their individual countries. In collecting the data, multiple sources of information have been used, such as databases, interviews, corporate documents, academic and trade journals. In addition, a database of the European Commission on Producer Organisations (POs) in the fruit and vegetables sector has been used to find internationally operating POs. As most of these POs have the legal form of a cooperative, they fall within the scope of this study. In addition, information on individual cooperatives has been collected by studying annual reports, other corporate publications and websites. In addition to the interviews which have been conducted with representatives of national associations of cooperatives, managers and board members of individual coop- eratives and academic and professional experts on cooperatives.

All data has been organized in the SFC database and details about internationalization and transnationalization of specific cooperatives have been published in a number of SFC case study reports. Reports, also including the process of cooperatives becoming transnationals, are: the internationalization of sugar cooperatives, ${ }^{22}$ the internationalization of the second-tier cooperative Conserve Italia, ${ }^{23}$ the internationalization of BayWa and Agrial, $^{24}$ the international structure of $\mathrm{HKScan}^{25}$ and the strategies of several Dutch transnational cooperatives. ${ }^{26}$

The SFC database also provides specific knowledge of the national cooperative experts in the articles mentioned above as well as a list of international and transnational cooperatives. We have then clustered these cooperatives per sector and per country. In the following section we will present the findings on transnational and international cooperatives per sector and country.

\section{Recent Findings on Transnational and International Agricultural Cooperatives in the EU}

As of 2011, we counted only 47 transnational agricultural cooperatives in the European Union. Some of these transnational cooperatives were second-tier cooperatives, which means that their members are cooperatives from two or more countries. Many of these transnational cooperatives also have non-member farmer suppliers in several countries (this could be the same countries where they also have members or different countries). In addition, we found another 45 international cooperatives, thus cooperatives with foreign farmer suppliers who are not members.

Table 1 presents the number of transnational and international cooperatives in EU in the different sectors. The main sectors with transnational cooperatives are cereals, fruit and vegetables $(\mathrm{F} \& \mathrm{~V})$ and dairy. In addition, transnational cooperatives can be found in the sectors pork, cattle, poultry, eggs, genetics (cattle breeding), potatoes and input supply.

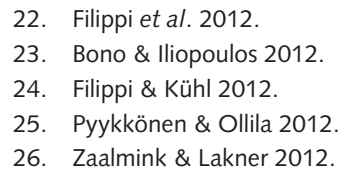


Tabel 1. The transnational and international cooperatives by sectors (2011)

\begin{tabular}{lll}
\hline & $\begin{array}{l}\text { Transnationals } \\
\text { (members in two } \\
\text { or more coun- } \\
\text { tries) }\end{array}$ & $\begin{array}{l}\text { Internationals } \\
\text { (members only } \\
\text { in one country } \\
\text { and suppliers in } \\
\text { other countries) }\end{array}$ \\
\hline $\begin{array}{l}\text { Fruit and Vegetables } \\
\text { (F\&V) }\end{array}$ & 15 & 15 \\
\hline $\begin{array}{l}\text { Cereals (usually com- } \\
\text { bined with feed for ani- } \\
\text { mal production) }\end{array}$ & 11 & 7 \\
\hline $\begin{array}{l}\text { Dairy } \\
\text { Sugar }\end{array}$ & 10 & 8 \\
\hline $\begin{array}{l}\text { Other sectors (meat, } \\
\text { eggs, potatoes, genet- } \\
\text { ics, inputs) }\end{array}$ & 9 & 3 \\
\hline Total & 2 & 12 \\
\hline
\end{tabular}

Source: Support for Farmers' Cooperatives project ${ }^{27}$

Most transnational cooperatives can be found in Northwest Europe, particularly in the Netherlands, Belgium, Denmark, Germany (34 out of 47). Also Ireland and Austria have several transnational cooperatives. Finally, one or two transnational cooperatives can be found in countries such as Italy, Finland, France, Luxembourg and Hungary. Figure 1 shows the geographical location of the transnational cooperatives.

The large number of transnational cooperatives in dairy and $\mathrm{F} \& \mathrm{~V}$ can be explained by the combination of small home markets and high market integration with neighbouring countries. The Netherlands, Belgium, Ireland and Denmark are all small countries but major producers of milk and/or $F \& V$. The dairy and $F \& V$ cooperatives from these countries have a long tradition of trading with neighbouring countries (e.g. Irish dairy exported to the UK). When domestic growth is limited due to a small home market, cooperatives are likely to seek expansion abroad, through both internationalization and transnationalization.

Transnationalization into neighbouring countries seems to be supported by increasing market integration, which means that markets are similar and that substantial trade between these markets exists. This market integration is facilitated by small distances, similar distribution patterns and similar consumer preferences. In addition, the transnationalization of agricultural cooperatives is supported by similarities in production structure (size of farms, types of crops) and in culture (e.g. the Netherlands and part of Belgium share the same language).
We will now zoom into various sectors: fruit and vegetables, dairy and other sectors.

\subsection{Fruit and Vegetables}

Transnational cooperatives in the $\mathrm{F} \& \mathrm{~V}$ sector exist in the Netherlands, Belgium, Germany, Hungary, Italy and Austria (Figure 2). The five largest $F \& V$ cooperatives in Belgium and three largest in the Netherlands are all transnational cooperatives. In Germany there are two transnational cooperatives in this sector. Both are multipurpose cooperatives (Landgard and BayWa) with large turnover outside the $\mathrm{F} \& \mathrm{~V}$ sector. Landgard's $\mathrm{F} \& \mathrm{~V}$ share of total turnover is about $40 \%$ whereas in BayWa $\mathrm{F} \& \mathrm{~V}$ account for less than $5 \%$ of the agricultural division's turnover. In Hungary there is one small transnational cooperative (turnover less than 3 million euro). The Italian transnational case is FINAF (First International Association Fruit), which is a second-tier fruit cooperative (and a registered Association of Producer Organisations) with two French and seven Italian member cooperatives.

The large market shares of transnational cooperatives in the Netherlands and Belgium, and the fact that Belgian cooperatives have members from the Netherlands while Dutch cooperatives have members in Belgium, indicate a high integration between these markets. ${ }^{28}$ Distances are short, production structures and crop choices are similar, language is the same and consumer preferences are similar. Dutch growers have become members of Belgian F\&V auctions because they favour the auction clock above bilateral negotiation as price determination method. Auction clocks were also used in the past in the Netherlands but were largely abolished in the late 1990s. The F\&V Dutch cooperatives have members in other countries in order to supply retail customers not only with Dutch produce but also with local products (particularly in the UK), or to make sure they have sufficient supply year-round (by sourcing from members in Southern Europe).

Some of the most recently established transnational cooperatives in the $\mathrm{F} \& \mathrm{~V}$ sector are actually transnational Associations of Producer Organisations (APOs) set up by national cooperatives. Examples of such transnational APOs are EFC (handling fresh fruits, established in 2002) and In-Co (in vegetables for processing industry, established in 2005). Both have cooperatives/POs from Belgium, the Netherlands and Germany as their members. This type of collaboration is supported by low cultural distance, short physical distances and common language (at least between the Netherlands and Flanders). For more details on these transnational cooperatives in Belgium and the Netherlands, see the SFC reports on EFC and on the comparison between Belgium and the Netherlands. ${ }^{29}$

\subsection{Dairy}

In the dairy sector there are two large transnational cooperatives, namely Arla Foods (Denmark/Sweden) 


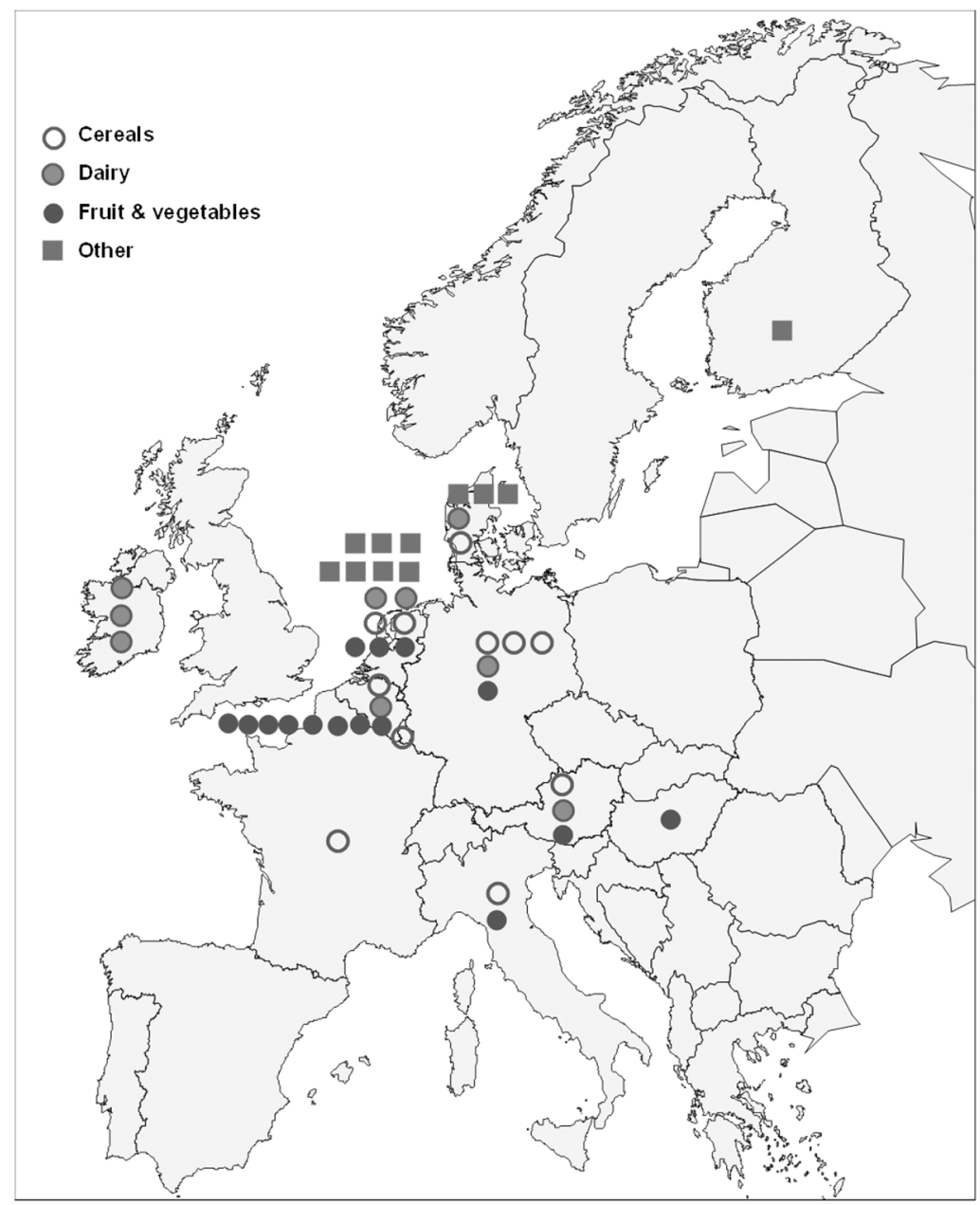

and FrieslandCampina (the Netherlands). In addition, there are several medium-sized (turnover 400-800 million euro) and some very small transnational dairy cooperatives in the EU. In the Netherlands, Denmark, Ireland and Sweden, the transnational cooperatives clearly have a dominant market position. Other transnational cooperatives can be found in Belgium, Austria and Germany (Figure 3).

\subsection{Other Sectors}

In addition to transnational cooperatives in the dairy and $F \& V$ sectors, we found transnational cooperatives in cereals (11 cooperatives, which often combine cereals trade and feed production), horticulture inputs (2), genetics (2), pork (1), mushroom compost (1), slaughterhouse by-products (1) and eggs (1). We will provide details about the pork sector, the egg sector and the cereal sector.

The unique transnational cooperative in pork is HKScan, headquartered in Finland. HKScan is an interesting case, as it has a complex ownership structure. The company is publicly listed on the Helsinki stock exchange but has two cooperatives as majority owners. The Finnish LSO has $68 \%$ of the voting rights and the Swedish Svenska Djurbönder has 12\% of the voting rights. HKScan was established in 2008 when the Finnish HK Ruokatalo acquired Swedish Meats that had been in economic troubles for years. ${ }^{30} \mathrm{With}$ a turnover of more than two billion euro, HKScan is one of the largest slaughterhouses in Europe. Next to having members in Finland and Sweden, it has suppliers in Estonia, Latvia and Lithuania. For more details on HKScan, see the SFC reports on HKScan and its cooperation with another cooperative, Danish Crown. ${ }^{31}$

The egg cooperative Danaeg is the result of the 2004 merger between Danish Danaeg and Swedish Kronägg (for Kronägg the merger was a way out of economic crisis). The Swedish members became members of the Danish cooperative and the Swedish business was incorporated in the limited liability company Kronägg AB. More recently, Danaeg and Finnish cooperative Munakunta started collaborating by establishing the $50 / 50$ joint venture Muna Foods Oy.

Cereal cooperatives were also ranked high on the list of transnational cooperatives (Table 1), but when looking more closely most of these cooperatives also have animal feed activities, and the foreign members are farmers that purchase feed and not necessarily farmers that deliver grains.

30. Westerlund Lind 2011.

31. Pyykkönen \& Ollila 2012; Pyykkönen et al. 2012. 
Figure 2 Transnational cooperatives in FEV sector-home countries and host countries (the solid line refers to member relationships, the dotted line to supplier relationships and the size of the "balls" represent the total turnover of the transnational)

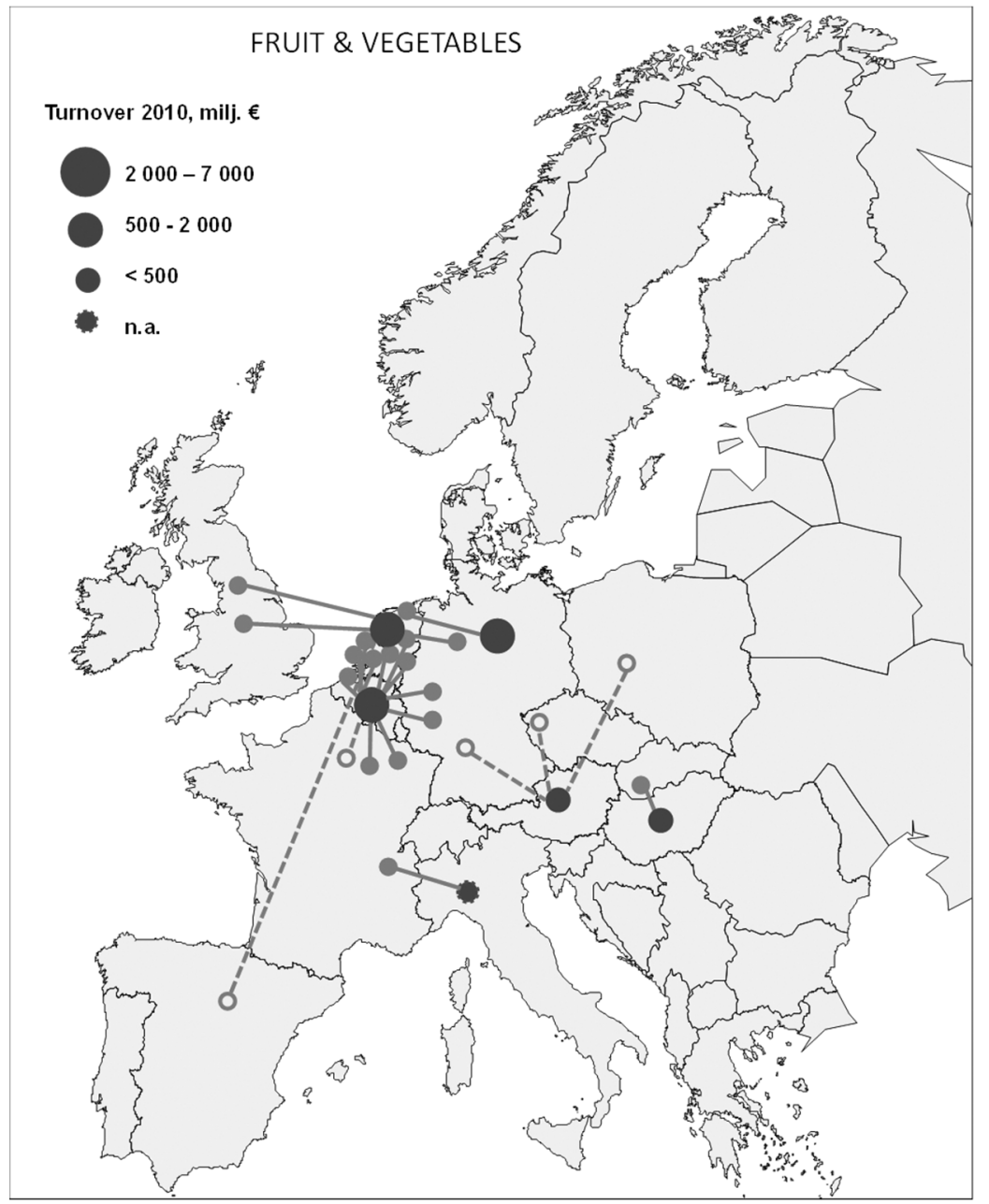

\section{Discussion:}

\section{Transnationalization and Internationalization Patterns in the EU}

In this section we want to discuss the above findings and specify the transnationalization and internalization patterns for regions, countries, sectors and types of cooperatives. We will also address the various motives for cooperatives to invite foreign suppliers to become members.

\subsection{There Are Significant Differences between Regions and Countries}

International and transnational cooperatives can be found mainly in Northern Europe. This can be explained by the small size of some of the Northern European countries like the Netherlands, Belgium, Ireland, Denmark, Finland. In order to remain cost-efficient, specialized dairy and meat cooperatives in these countries have been forced to seek international expansion. While this efficiency argument originally applied to large-scale processing, nowadays it also applies to investments in $\mathrm{R} \& \mathrm{D}$ and marketing. We may add that there is also path dependency as both Denmark and the Netherlands have a long tradition of export of agricultural products, going back to the 19th century when both countries were major suppliers of food to industrializing England. Finally, relatively homogeneous consumption patterns allow food processing cooperatives to utilize economies of scale in producing and marketing similar products.

Germany, however shows another pattern despite having economic and cultural characteristics similar to the Netherlands, Denmark and Belgium. The cooperatives from Germany are much less internationalized, due to the large domestic market. Theuvsen and Ebneth argued that it is the combination of small home markets with specialized cooperatives (in dairy and meat) that leads to internationalization. ${ }^{32}$

France is an interesting case of internationalization. France is one of the major agricultural producers in Europe, and cooperatives play a dominant role in the agricultural sector. Many large French cooperatives in cereals (e.g. Axereal and Champagne Céréales), in dairy

32. Theuvsen \& Ebneth 2005 
Figure 3 Transnational cooperatives in dairy sector-mother countries and host countries (the solid line refers member relationships, the dotted line refers to supplier relationships and the size of the "balls" represents the total turnover of the transnational cooperative)

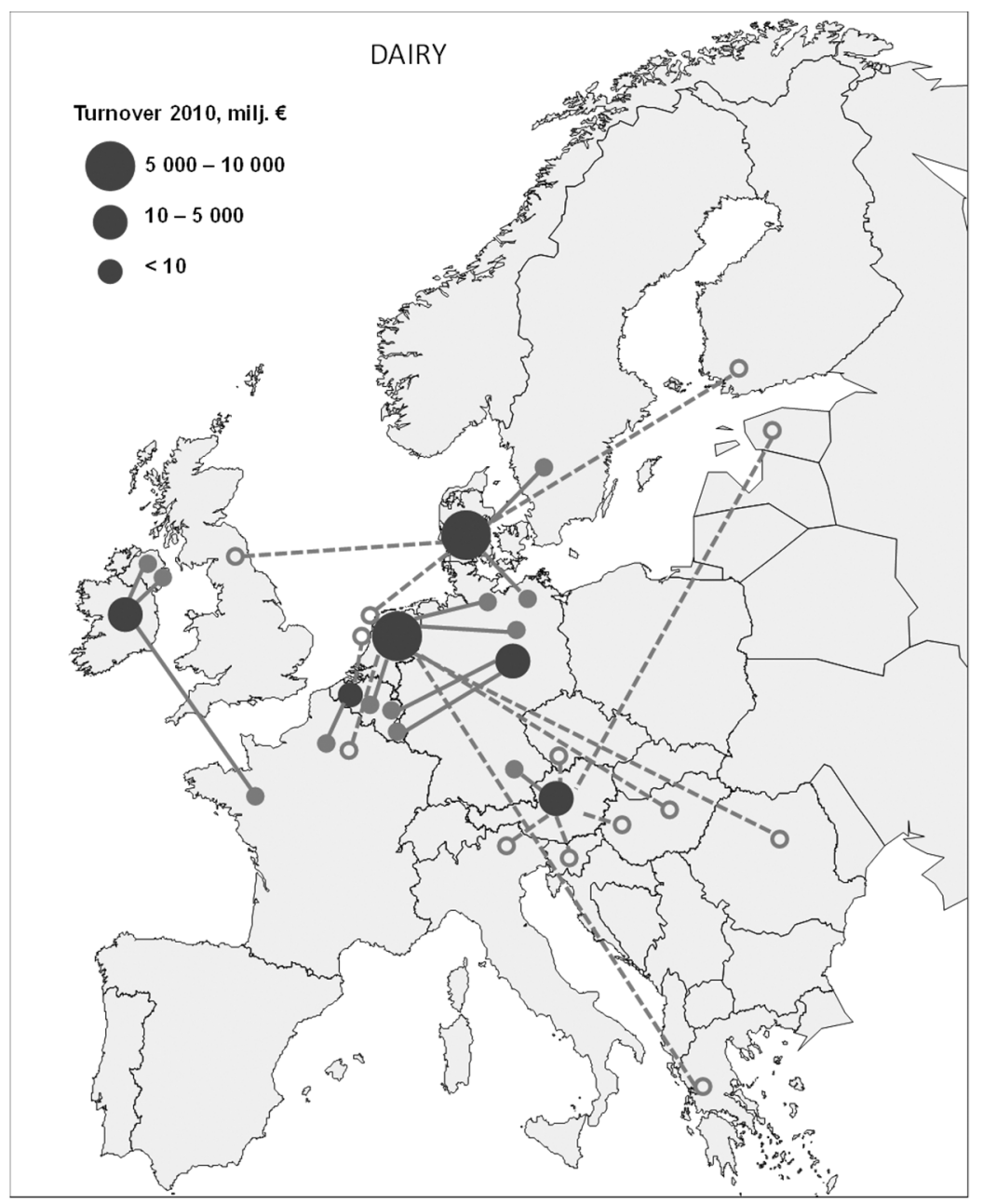

(e.g. Sodiaal), in processed vegetables (e.g. Agrial and Cecab), in sugar (e.g. Tereos) and in supplying seeds (e.g. Maisadour and Limagrain) have foreign subsidiaries that purchase agricultural products from or supply agricultural inputs to foreign farmers. ${ }^{33}$ Still, our data shows that French cooperatives do not have members abroad. In other words, French cooperatives are internationalized but not transnationalized. A possible explanation could come from the French tradition of terroir. Cooperatives in France require official authorization from regional authorities, permitting them to operate in that region, but only within the economic sector specified in the application and only within the limits of a specific and restricted territory. ${ }^{34}$

International cooperatives from Southern Europe are more likely to be second-tier cooperatives, as the examples of Conserve Italia (from Italy) and Anecoop (from Spain) show. These federated cooperatives are engaged in processing and marketing of the products delivered by the member cooperatives, mainly fruits and vegetables. These international cooperatives are less likely to become transnational, as the second-tier cooperatives do not engage in direct farmer-relationships.

Cooperatives are most likely to find their foreign members in neighbouring countries. This is not surprising, as market and cultures are more likely to be similar in neighbouring countries than in distantly located countries. Culture seems to be an important explanation for the extent of transnationalization (see below).

\subsection{Internal Governance Does Affect Transnationalization}

As the cases of Conserve Italia and Anecoop already showed, internal governance affects the degree of internationalization. Theuvsen and Ebneth suggest that cooperatives that have transformed into holding companies and have appointed professional managers to run the cooperative firm are more likely to go international. ${ }^{35}$ While from a business perspective internationalization seems a normal growth strategy, cooperatives are still entrenched in local and regional cultural and institutional settings. Bijman et al. found that several cooperatives have made a de jure and de facto separation between cooperative firm and cooperative association, 
which allows the management to obtain more discretion to enter into international business ventures. ${ }^{36}$ Compared to the 'pure' cooperative structure, a separation of cooperative association and cooperative firm makes performance evaluation and remuneration of the management more easy. In France, all of the international cooperatives are so-called cooperative groups, ${ }^{37}$ where a regional embedded cooperative has established a holding company that has subsidiaries both outside the own region and outside the country.

While Nilsson and Madsen argue that cross-border mergers are often initiated by the management, ${ }^{38}$ Zaalmink and Lakner found that managers prefer to run the foreign operation like an $\mathrm{IOF},{ }^{39}$ as the latter is much easier to manage than a transnational cooperative. Also the performance criteria for the managers and deciding on performance-dependent remunerations are much easier in IOF-type of subsidiaries. ${ }^{40}$

\subsection{Newly Identified Motives for Cooperatives to Become Transnational}

For some cooperatives, merging with foreign counterparts (strategy 4, section 2) is just a continuation of the domestic process of mergers at the moment that domestic mergers are no longer possible (mainly due to competition law restrictions). The main advantage of growth through mergers is that it does not require large investments (which the members may not like, or the banks may not be willing to provide such large loans due to the relatively low profitability). For these financial reasons, mergers provide an important gromth mechanism for cooperatives.

The traditional reasons to search for foreign membership have been resource seeking and efficiency seeking. In order to benefit from technological developments in processing and consequent increases in operational efficiencies and volumes, cooperatives have to find new resource suppliers. By offering membership to suppliers, the necessary supplies could be assured. Thus, safeguarding access to supplies has become a motive for cooperatives to pursue foreign membership. This strategy also fits into the supply chain perspective and becomes even more important for those cooperatives which became preferred suppliers of major retail customers in order to better safeguard sufficient supply of the right quality products. Particularly the importance of product quality and product safety leads cooperatives to establish tighter relationships with their foreign suppliers, which can be more easily obtained if those suppliers are members.

For some cooperatives, inviting foreign suppliers to become members is directly driven by the changes in the marketing perspective. For example, the increasing demand for local and regional products made this a necessity. Over the last decade, the regional origin of food

\footnotetext{
Bijman et al. 2014.

Filippi 2012.

Nilsson \& Madsen 2007

Zaalmink \& Lakner 2012.

Bijman et al. 2014.
}

products has become more important. ${ }^{41}$ An increasing number of consumers has a preference for products that are produced not far from the location of consumption, either because they have more confidence in local production conditions or because they want to support the local economy. Other consumers are more concerned about the environmental impact of long distance transport of food products. ${ }^{42}$ This leads to a trend where local consumption and local production become (re)connected. For cooperatives selling products in different countries, the trend towards local-to-local chains may be a reason to establish closer relationships with foreign suppliers. Again, this can be done more easily if the suppliers are members. This is particularly relevant for fruit and vegetables, as consumers are most concerned about the number of food miles of those products. This argument has been mentioned by vegetables cooperative Coforta/The Greenery. ${ }^{43}$

\subsection{Type of Cooperative and the Preference to Go Transnational}

Studying cooperatives, usually a distinction is made between supply cooperatives (supplying inputs to farmers) and marketing cooperatives (selling farm products, either fresh or after processing). Among marketing cooperatives, we find most transnational cooperatives in the fruit and vegetables and dairy sectors. The most likely explanation of this lies in transaction cost economics. ${ }^{44}$ The combination of the perishability of the product, high uncertainty about trading partners and the high asset specificity (particularly for dairy) leads to high transaction costs. Setting up a cooperative, or joining an existing cooperative, has been a proven strategy for farmers to reduce transaction costs. ${ }^{45}$

When cooperatives are dominant in the milk sector in the neighbouring country, a cooperative that wants to expand abroad may not have much choice but to merge with a foreign cooperative (strategy 4 , section 2 ). This is exactly the model of internationalization that Arla is following in Germany, Belgium and the UK.

Do we also expect supply cooperatives to become transnationals? Although there are several transnational supply cooperatives, we conjecture that supply cooperatives are less likely to become transnational, as they have a different type of relationship with their members than marketing cooperatives. In choosing a supplier of seeds, feed, starting material, equipment and fertilizers, farmers usually have several options available, while in selling their products they often have limited options. In addition, managing a supply cooperative is more difficult due to the heterogeneous demands of the members and the large assortment of products needed. Moreover, according to most statutes of supply cooperatives, members are not obliged to purchase their inputs from the cooperative.

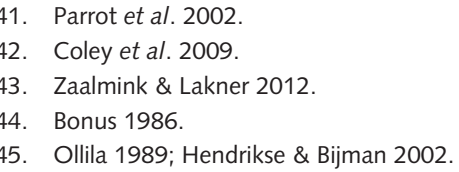


The sugar industry is an interesting case. While European sugar cooperatives are very international in the sense that they all have processing facilities and suppliers abroad, they hardly have any foreign members. The four sugar cooperatives studied by Filippi et al. have all acquired foreign companies and they continue to contract with the suppliers of those companies without integrating them into a cooperative membership system. ${ }^{46}$ Thus, the cooperatives are behaving in their international operations like IOF-type of companies. There may be two explanations for this. First, all foreign acquisitions by the cooperatives have been noncooperative companies. The farmer-suppliers did not have membership relations with their buyers, so there was no demand on behalf of the farmers to become members. Contractual relations were continued. Second, for the cooperative, making these suppliers as members would have led to additional costs in terms of language, decision-making and traveling. Obviously, the benefits of transnationalization did not outweigh the costs.

\subsection{Motives for Cooperatives to Not Invite Foreign Suppliers to Become Members}

Zaalmink and Lakner have explored what arguments Dutch international cooperatives put forward for not inviting foreign suppliers to become members. ${ }^{47}$ The main reasons relate to expected higher costs due to differences in language (cost of translations, interpreters) and to differences in legal systems (higher cost of legal advice). Also mentioned were the differences in the culture of a cooperative membership. Despite several Dutch cooperatives having German members, most cooperatives emphasized the differences between Dutch and German farmers in their relationship with their cooperative. Dutch farmers are more likely to invest in the cooperative (or allocate a part of the earnings to the general reserves), while German farmers are more likely to demand the highest price from their cooperative. Another reason not to invite foreign suppliers to become members of Dutch cooperatives is the fear of dilution of control rights and residual claims. Current members are reluctant to share the benefits of financial and physical assets that have been built up over generations, unless new members have to buy into the cooperative. The latter may be difficult to organise, or it may be just too costly for potential new members.

Heterogeneous interests may indicate that the horizon problem can also be revisited. Another example of this fear of dilution of property rights has been documented by Pyykkönen and Ollila who found in the case of Sokolow that this may also be the reason for HKScan to act like an IOF in other countries. ${ }^{48}$ Cooperatives (or to be accurate the companies they hold) invite producer suppliers but do not offer the possibility to become a member in the cooperative.

46. Filippi et al. 2012

47. Zaalmink \& Lakner 2012.

48. Pyykkönen \& Ollila 2012.
Other barriers for transnationalization may be found in the differences among countries in rules on voting rights (e.g. proportional versus one-member-one-vote), differences in member entitlements (individual versus collective equity capital) and differences in rules and traditions of surplus distribution. Internationalization instead of transnationalization seems to circumvent many of those problems.

\section{Conclusion}

Transnationalization of agricultural cooperatives in Europe seems to be increasing, however, only in a limited number of countries and a limited number of sectors. Most of the transnational cooperatives can be found in Belgium, the Netherlands, Germany, Ireland and Denmark. Dairy and fruit and vegetables are the most important sectors. The EU policy on producer organizations (POs) in the fruit and vegetables industry has promoted not only the establishment of new POs but also Associations of POs and international collaborations among POs.

Several trajectories have been followed by cooperatives that have become transnational. Some have invited suppliers from just on the other side of the border to become member. Efficiency is the main argument here. Other cooperatives have merged with foreign counterparts. This implies an explicit strategy of growth through internationalization. A third group has acquired assets from foreign cooperatives (without a formal merger) and have then invited the members of the foreign cooperative to become member in the acquiring cooperative. Having close supplier relationships is the dominant argument here, and dairy is the typical sector. Finally, in fruit and vegetables, we find two models of transnationalization. The first model is that national cooperatives set up an international cooperative as the second tier (thus, the members of the transnational cooperative are local cooperatives, not farmers). The second model is where farmers from two or more countries set up a new transnational cooperative.

Some transnational cooperatives have rather complex and hybrid ownership structures. Farmers are members of a national cooperative which has, together with cooperatives from other countries, established a second-tier transnational cooperative. This transnational cooperative is a holding with several subsidiaries. These subsidiaries source their products from farmers who are members of one of the national cooperatives. These subsidiaries may also source from farmers that are not members of a participating cooperative. Such holding structures, where most of the transactions between members and cooperative are actually between members and a limited liability subsidiary of the cooperative holding, are less likely to seek foreign membership.

Transnationalization of cooperatives continues to meet many obstacles. Not only differences in language, legal systems and culture of collaboration may restrain coop- 
eratives from obtaining foreign members, also current members seem reluctant to let their cooperative turn into a transnational cooperative. Having foreign members increases the heterogeneity of the membership, thus increases decision-making costs and leads to potential dilution of both decision rights and income rights. Reluctant members find managers on their hand, as managers prefer to manage the foreign subsidiary as a profit centre instead of having to deal with foreign members. Thus, we expect that the international growth of agricultural cooperatives will be mainly in the form of international cooperatives and not transnational cooperatives.

\section{References}

W.J. Bijman \& R.J.M. van Tulder, "Internationalization and Vertical Relationships in the Dutch Agrifood Sector", in G. Galizzi \& L. Venturini (eds.), Vertical Relationships and Coordination in the Food System, Heidelberg, Physica Verlag 1999, pp. 197-210.

J. Bijman et al., "Support for Farmers' Cooperatives", Country Report The Netherlands, Wageningen, Wageningen UR 2011.

J. Bijman et al., "Support to Farmers' Cooperatives", Final Report, Wageningen, Wageningen UR 2012.

J. Bijman \& A. Saris, "Support for Farmers' Cooperatives", Case Study Report European Fruit Co-operation (EFC), Wageningen, Wageningen UR 2012.

J. Bijman \& C. Gijselinckx, "Support for Farmers' Cooperatives", Case Study Report, Fruit and Vegetables Cooperatives in the Netherlands and Belgium, Wageningen, Wageningen UR 2012

J. Bijman, M. Hanisch \& G. van der Sangen, "Shifting Control? The Changes of Internal Governance in Agricultural Cooperatives in the EU", 85 Annals of Public and Cooperative Economics 4, 2014, pp. 641-661.

P. Bono \& C. Iliopoulos, "Support for Farmers' Cooperatives", Case Study Report, Internationalization of Second-tier Cooperatives: The Case of Conserve Italia, Italy, Wageningen, Wageningen UR 2012.

H. Bonus, "The Cooperative Association as a Business Enterprise: A Study in the Economics of Transactions", 142 Journal of Institutional and Theoretical Economics / Zeitschrift für die gesamte Staatsmissenschaft, 1986, pp. 310-339.

D. Coley, M. Howard \& M. Winter, "Local Food, Food Miles and Carbon Emissions: A Comparison of Farm Shop and Mass Distribution Approaches", 34 Food Policy, 2009, pp. $150-155$.

I. Donoso et al., "The Internationalization of Agricultural Cooperatives : Critical Factors in Development”, Agribusiness Perspectives Papers 61, New Zealand, Massey University 2003.

J.H. Dunning, Multinational Enterprises and the Global Economy, Wokingham [etc.]: Addison-Wesley 1992.

EURICSE, Study on the implementation of the Regulation $1435 / 2003$ on the Statute for European Cooperative Society, 5 October 2010, Euricse/Cooperatives Europe/Ekai

Federation of Danish Co-Operatives, Transnational Co-operatives. Perspectives of admission of members abroad and crossborder mergers. Copenhagen: The Federation of Danish Cooperatives 2000.

M. Filippi, "Support for Farmers' Cooperatives", Country Report France, Wageningen, Wageningen UR 2012.

M. Filippi, O. Frey \& A. Torre, "The Modalities of Territorial Embeddedness of French Cooperative Groups", in A. Torre \&
J.B. Traversac (eds.), Territorial Governance, Rural Areas and Agrofood Systems, Springer Book 2011, pp. 43-65.

M. Filippi \& R. Kühl, "Support for Farmers' Cooperatives”, Case Study Report: Agrial (FR), BayWa (DE) and internationalization, Wageningen, Wageningen UR 2012.

M. Filippi, R. Kühl \& B. Smit, "Support for Farmers' Cooperatives", Case Study Report: Internationalization of Sugar Cooperatives: Cosun, Südzucker/Agrana, Tereos, Wageningen, Wageningen UR 2012.

R. Guillouzo \& P. Ruffio, "Internationalization of European Dairy Cooperatives", 2 International Fournal of Cooperative Management 2, 2005, pp. 25-32.

M. Heyder, C. Makus \& L. Theuvsen, "Internationalization and Firm Performance in Agribusiness: Empirical Evidence from European Cooperatives", 2 Int. F. Food System Dynamics 1, 2011, pp. 77-93.

D. van der Krogt, J. Nilsson \& V. Høst, "The Impact of Cooperatives' Risk Aversion and Equity Capital Constraints on Their Inter-Firm Consolidation and Collaboration Strategies - with an Empirical Study of the European Dairy Industry", 23 Agribusiness 4, 2007, pp. 453-472.

J. Nilsson \& O.O. Madsen, "Issues in Cross-Border Mergers between Agricultural Co-operatives", 40 Fournal of Co-operative Studies 3, December 2007, pp. 27-38.

J. Nilsson \& P. Ollila, "Strategies and Structures in the European Dairy Co-operative Industry", 42 Fournal of Co-operative Studies 2, 2009, pp.14-23.

P. Ollila, "Coordination of Supply and Demand in the Dairy Marketing System - with Special Emphasis on the Potential Role of Farmer Cooperatives as Coordinating Institutions", 61 Fournal of Agricultural Science in Finland 3, 1989, pp. 135-321.

P. Ollila, "Aspects of Market Entry of the Finnish Food Industry into the German and Dutch Markets", 7 Fournal of International Food and Agribusiness Marketing 2, 1995, pp. 25-52.

P. Ollila \& P. Pyykkönen, "Support to Farmers' Cooperatives", Case Study Report; Cooperative Dairy Processor Valio structural development to its present stage, Wageningen, Wageningen UR 2012.

P. Ollila, J. Nilsson \& S. Hess, "The Internationalization of Cooperatives from a Farmer Perspective", 23 Agricultural and Food Science 4, 2014, pp. 291-306.

N. Parrott, N. Wilson \& J. Murdoch, "Spatializing Quality: Regional Protection and the Alternative Geography of Food", 9 European Urban and Regional Studies, 2002, pp. 241-261.

P. Pyykkönen \& P. Ollila, “Support for Farmers' Cooperatives”, Case Study Report HKScan hybridisation, Wageningen, Wageningen UR 2012.

A.M. Rugman \& S. Collinson, International Business, Harlow [etc.], Financial Times Prentice Hall 2009.

L. Theuvsen \& O. Ebneth, "Internationalization of Cooperatives in the Agribusiness : Concepts of Measurement and Their Application", in T. Theurl \& E.C. Meyer (eds.), Strategies for Cooperation, Germany, Shaker Verlag 2005, pp. 395-419.

J. Trienekens \& P. Zuurbier, "Quality and Safety Standards in the Food Industry, Developments and Challenges", 113 International Fournal of Production Economics, 2008, pp.107-122.

O.F. van Bekkum, G. van Dijk \& P. van Boekel, Agricultural Cooperatives in the European Union: Trends and Issues on the Eve of the 21st Century, Assen, Van Gorcum 1997.

Westerlund Lind, L., Market Orientation of the Swedish Pork Sector - The Case of the Demutualization of Swedish Meats. Acta Universitatis agriculturae Sueciae, 2011.

Zaalmink, W. \& D. Lakner, Support for Farmers' Cooperatives; Case Study Report. The Role of Dutch Transnational Cooperatives in Cooperative Development, Wageningen: Wageningen UR, 2012. 